\title{
Idolaters, Philosophers and an Elusive Jew
}

\author{
The Problem of Paganism in the Summa Halensis
}

\begin{abstract}
This chapter examines the Summa's treatment of the philosophers, by which it means, in the main, the ancient pagan philosophers, although some later Jewish and Islamic figures are also included. It shows how the authors balanced the obvious virtue and wisdom of the philosophers against their moral shortcomings, inevitable since they lacked God's grace, and the severe limitation to their understanding entailed by their limited understanding of the Trinity and their lack of explicit knowledge of the Incarnation. With regard to salvation, the authors seem not to have had a general theory about the fate of the philosophers, but they suggest that some might have been saved by special inspiration. The chapter also considers a more anthropological approach to the pagans in the Old Testament found in Summa Book 2, and it argues that there is no evidence of direct knowledge of Maimonides's Guide of the Perplexed in the Summa Halensis.
\end{abstract}

The large group of people often described as 'pagans'-all those who were not Christians, Jews or Muslims-posed a problem for Christian thinkers in the Middle Ages. These pagans included the philosophers, poets and heroes from antiquity whose wisdom and virtues many medieval writers so admired. How could pagans, given their ignorance of Christian truth, be the sources of scientific knowledge that the ancient philosophers were taken to be? Could pagans be truly virtuous, and, if not, why did so many famous figures of antiquity appear to have been so? And, if there were truly wise and virtuous pagans, how can it be explained that, at first sight at least, Christian doctrine seems to hold that they have been damned?

This 'Problem of Paganism' was central to the thought of some medieval writers; even for the many, such as the authors of the Summa Halensis (SH), who did not dwell on it, the Problem generated a tension, and investigating it throws a light on the character of their thinking. ${ }^{1}$ The first part of this paper will investigate each of these aspects of the Problem in the SH. The philosophers, however, are not the only sort of pagans discussed by the authors (as the writers of the $S H$ will be called here). The Old Testament, to which the $S H$ devotes so many columns, teems with pa-

\footnotetext{
1 I discuss the nature and history of the Problem of Paganism in my book, Pagans and Philosophers: The problem of paganism from Augustine to Leibniz (Princeton: Princeton University Press, 2015). There is a useful discussion of the views about non-Christians in the $S H$ in Elisabeth Gössmann, Metaphysik und Heilsgeschichte: Eine theologische Untersuchung der Summa Halensis (Munich: Hueber, 1964), 391-400: Excursus 'Die besondere Stellung der Philosophen im Unterschied zu dem Juden und Heiden'.
} 
gans: the ancestors of the Jews, in the time before they received God's law, and the many peoples they fought, defeated, or by whom they were conquered and enslaved. The $S H$ looks closely at idolatry and its origins in the Old Testament world, and also at the non-Jewish customs and sacrifices of those times. The second part of this paper concerns this anthropological interest in pagans, another strand in the Problem of Paganism, related to each of its three main aspects. A first indication of the SH's attitude towards the Problem is provided, however, by the terms it uses and the particular ways in which they are made to refer.

\section{Pagans, Saracens, Jews, Idolaters and Philosophers}

The term 'pagans' (pagani) has a variety of meanings, both in its medieval usages and today. In one sense, pagani, and also gentiles, designates people who are not Christians, Jews or Muslims. The ancient Greeks and Romans, the Philistines of the Old Testament, and $13^{\text {th }}$-century Lithuanians or Mongols are all, by this terminology, 'pagan'. It is about paganism understood in this common sense that I formulated the phrase 'the Problem of Paganism', as used in the title and just discussed. The $\mathrm{SH}$, however, has a different terminology.

The authors make an explicit division of non-Christians (the infidels or non-faithful) in a single passage. ${ }^{2}$ There are the 'Saracens' (saraceni) or 'pagans' (pagani) who believe that there is one God and do not worship idols, but do not believe in the Incarnation or in the Mosaic Law, and accept neither the Old nor the New Testaments. Then there are the Jews, who accept 'the Law given by God', but not the New Testament, and believe that God is one and their liberator, but do not believe in the Incarnation. Finally, there are the 'idolators' (idololatrae), 'who adore idols for God and who believe in not just one God, but many'.

The authors here have in view principally the division of non-Christian peoples in their own time, but at the back of their minds, they also have the Old Testament. The term 'Saracens' points to the Muslims, and 'pagans' seems to be used just, as in some of the legal documents quoted in $S H$, as a synonym for it (and, true to this usage, the $S H$ does not generally use pagani to refer to the idolatrous, non-Jewish

2 Alexander of Hales, Doctoris irrefragabilis Alexandri de Hales Ordinis minorum Summa theologica (SH) (Quaracchi: Collegium S. Bonaventurae, 1924-48), Vol III, In3, Tr8, S1, Q1, p. 715: 'Pagani autem sive Saraceni dicuntur illi qui nec Novum nec Vetus Testamentum recipiunt omnino, sed suis utuntur traditionibus, et, licet credant unum esse Deum nec adorent idola, non credunt incarnationem nec ea quae in lege Moysi continentur. Iudaei vero sunt qui Legem datam a Domino receperunt et unum Deum credunt creatorem et liberatorem, sed Novum Testamentum non recipiunt nec incarnationem Filii Dei credunt. Idololatrae vero dicuntur illi qui idola pro Deo adorant et non solum unum Deum credunt, sed plures, quos etiam Augustinus, in libro Contra quinque haereses, paganos vocat. Ibi enim sub duabus differentiis hae tres differentiae comprehenduntur: quidam enim dicuntur Iudaei, quidam pagani, utrobique autem notatur infidelitas.' 
peoples of the Old Testament, except in quotations). The characterization given-involving the rejection of the Bible and the Incarnation, as well as the rejection of idolatry and the acceptance of One God-fits the understanding of Muslims among educated medieval Churchmen. Then there are the Jews, and finally the idolaters. These idolaters could correspond to the peoples in the North or beyond Islam, of whom the authors may have had some vague knowledge. ${ }^{3}$ They also fit the gentiles-the idolatrous tribes who were enemies of the Israelites, in the Old Testament, a book the authors knew very well.

In the detailed discussion that follows, the treatment of non-Christian religions is divided between a biblical and a present-day focus. It begins with a treatment of idolatry, which uses only evidence provided in the Bible. After this, the authors concentrate on the Jews, the one non-Christian group with whom Christians in Europe had regular contact. The pagani are mentioned in the course of an argument (which is rejected) that Jews should not be tolerated, because Christians wage war and try to kill the pagani who occupy the Holy Land; here they are clearly referring to the Muslims. ${ }^{4}$ In questions about whether Jews can have Christian servants or Christians Jewish ones, the pagani (to whom the same is said to apply) are added as an afterthought. ${ }^{5}$

It says something about the authors' priorities that this explicit three-fold classification leaves no room for people who are neither Christians, Jews nor Muslims, nor idolaters. But the authors do not, in fact, exclude this group entirely. They talk in various places about the 'philosophers', or describe a writer as a philosophus, and although this term is not part of their official classification of religions, their discussions indicate that usually they regard philosophers as both not being idolaters and not belonging to one of the Abrahamic religions.

Unlike any of the groups in their threefold classification, 'philosophers' are always figures from the past, referred to by the authors in the past tense. Most often the term refers to Aristotle and his followers and Aristotle himself is called, as he would be throughout the rest of the Middle Ages, simply 'the Philosopher' (philosophus). But Plato too is included among the philosophers. ${ }^{6}$ Sometimes the term refers to the philosophers as cited by Augustine, ${ }^{7}$ and it is also used to refer to the pagans of Rom. 1:21 who knew God but did not glorify him as they should. ${ }^{8}$ The term is also used for more recent figures from the Islamic world, especially Avicenna, ${ }^{9}$ sometimes

3 Cf. Marenbon, Pagans and Philosophers, 68-70.

4 SH III, In3, Tr8, S1, Q2, Ti2, M1, C1 (n. 740), p. 729.

5 SH III, In3, Tr8, S1, Q2, Ti2, M2, C2 (n. 746), pp. 733-5; SH III, In3, Tr8, S1, Q2, Ti2, M2, C4 (n 748),

p. 736.

6 SH II, In1, Tr2, Q5, C4 (n. 96), p. 118.

7 SH I, P1, In1, Tr5, S2, Q3, Ti2, C2, Ar2 (n. 214), pp. 308-9; SH I, P1, In1, Tr5, S2, Q3, Ti2, C4 (n.218),

p. 313; SH II, In4, Tr2, S2, Q1. Ti1 C4 (n. 456), p. 587.

8 SH IV, P3, In2, Tr2, Q2, Ti3 (n. 707), p. 1141.

9 SH I, P1, In1, Tr3, Q1, M1, C3 (n. 74), p.117; SH II, In1, Tr1, S1, Q2, Ti2, C6 (n. 26), p. 37. 
explicitly identified as following Aristotle. ${ }^{10}$ The authors also talk of 'Maimonides and other philosophers' ${ }^{11}$ On one occasion, the term 'Philosophus' designates, not Aristotle, but Abu Mashar; ${ }^{12}$ on another occasion the authors refer to 'the philosopher, that is to say, Isaac'-alluding to a medical text by the $9^{\text {th }}$ - to $10^{\text {th }}$-century Jewish philosopher and physiologist Isaac Israeli. ${ }^{13}$

As this list indicates, the authors did not use the term 'philosopher' as such to indicate a given religious group-since a philosopher might be a Muslim or a Jew, though apparently not a Christian. But the word could cover those figures from the ancient world, such as Plato and Aristotle, who had not rejected but simply did not know the Old Testament, and were not idolaters. ${ }^{14}$ In the case of the $S H$, to examine the themes of what elsewhere are often called pagan virtue, pagan wisdom and the salvation of pagans will mean looking at the philosophers, and what the authors say about their virtues, wisdom and salvation.

\section{The Philosophers' Virtues}

The theme of philosophers' virtues in the $S H$ can be treated quite briefly. Theologians usually dealt with questions about pagan virtue when discussing the virtues in general, but the section on the virtues in general, though promised, is missing from the SH. The authors' position must be gathered, therefore, by contextualizing their passing remarks within the medieval debate.

On the one hand, very few medieval authors accepted Augustine's position that pagan virtues were not virtues at all. On the other hand, even so great an admirer of the ancient, pagan world as Abelard accepted, following Augustine, 'that every virtue is charity or from charity', apparently thus denying the possibility of virtue to those without grace. ${ }^{15}$ Indeed, Peter the Lombard's definition of virtue as 'a good quality of the mind, by which one lives rightly and no one uses badly, which God alone works in a human being' seemed to rule out as virtues any but infused ones-and the authors take this definition but underline God's role even more heavily, changing its ending to 'which God works in us without us'. ${ }^{16}$ The usual strategy, from Simon of

10 SH I, P1, In1, Tr3, Q1, M1, C3 (n. 74), p. 119.

11 SH I, P1, In1, Tr4, Q4, C6 (n. 162), p. 242: 'Rabbi Moyses et alii philosophi'.

12 SH II, In4, Tr2, S1, Q1, C3 (n. 430), p. 511.

13 SH II, In 4, Tr2, S1, Q3, Ti2, M2, C2, Ar1 (n. 438), p. 533: 'Philosopho, scilicet Isaac'.

14 But it could also be, though rarely was, used for idolaters, since the 'philosophers' of Rom. 1:21 (see above, n. 8) who knew God but did not glorify him are described as having turned to worshipping created things in place of God.

15 See Peter Abelard, Sententie, s. 251, in Petri Abaelardi opera theologica, vol. 6, ed. David Luscombe, Corpus Christianorum Continuatio Mediaevalis, 14 (Turnhout: Brepols, 2006), 132:2986; Marenbon, Pagans and Philosophers, 88.

16 See Peter Lombard, Sententiae in IV libris distinctae II, d. 27, c. 1, 2 vols, ed. Ignatius C. Brady, Spicilegium Bonaventurianum, 4-5 (Grottaferrata: Editiones Collegii S. Bonaventurae, 1971-81), 
Tournai and Alan of Lille in the later $12^{\text {th }}$ century onwards, was to say that pagans could have 'political' virtues-a label taken from Macrobius-and leave their relation to the virtues founded on charity vague: they were not exactly false virtues, but nor were they real ones. ${ }^{17}$ The $S H$ apparently follows this line. Virtue in the very broadest sense is divided into natural, political and graced varieties; in a less, but still very broad sense, it is divided into political virtue, which is acquired, and graced virtue, which is infused. ${ }^{18}$ As the authors say: 'the aim of the moral philosopher is civic happiness, and he goes no further ( ... ) But the theologian sets eternal happiness as his end. ${ }^{19}$

In keeping with this outlook, the authors insist that the philosophers 'never came to the knowledge of grace or of graced good'. ${ }^{20}$ Nor did they know about the Fall, the event that made grace necessary: 'According to the catholic truth, it must be acknowledged that human nature is fallen. But this is something that the philosophers did not know. ${ }^{21}$ In itself, this position would have been accepted by every $13^{\text {th }}$-century Christian thinker, but it has especially serious consequences in the $\mathrm{SH}$, because the Fall, and grace, are so central to its outlook. For instance, the authors go so far as to deny that the philosophers knew of free will (liberum arbitrium). They realize that this position sounds extreme, and they explain that one meaning of the term is 'the rational power for opposites', and in this sense the philosophers did indeed know about it. But the sense that the authors consider most important is free will as the starting point for merit, and to be such, it must be recognized as coming from God. And free will in this sense was unknown to the philosophers. ${ }^{22}$

1:480: 'Virtus est, ut ait Augustinus' bona qualitas mentis, qua recte vivitur, et qua nullus male utitur, quam Deus solus in homine operatur'; cf. SH IV, P3, In1, Tr1, Q2, C1, Ar4 (n. 611), p. 964: 'Definit Augustinus virtutem dicens: "Virtus est bona qualitas mentis qua recte vivitur, qua nemo male utitur, quam Deus operatur in nobis sine nobis".' Although both Peter the Lombard and, following him, the authors attribute the definition to Augustine, it is in fact a formulation suggested by phrases in Augustine but put together, probably by Peter himself.

17 Cf. Marenbon, Pagans and Philosophers, 161.

18 SH IV, P3, In1, Tr2, Q2, Ti1, M3 (n. 651), p. 1034: 'Communius dicitur secundum quod virtus tantum extenditur ad virtutem politicam, quae est habitus acquisitus, et gratuitam, quae est habitus infusus.' 19 SH III, In3, Tr4, S2, Q1, Ti5, C7, Ar3 (n. 580), p. 567. The whole passage runs: '(...) finis moralis Philosophi est felicitas civilis nec ultra progreditur. Qui vult conservare pacem civitatis, necesse est ut in hoc attendat differentiam, ut magnis det magna et parvis parva, et ideo aliam medietatem et alia extrema determinat circa haec et circa illa: unde sua extrema ponit secundum parvum et magnum. Sed theologus attendit tamquam pro fine felicitatem aeternam: Philosophus enim ad hunc finem non potuit pervenire natura et ratione, sicut potuit fidelis argumento gratiae et ex adiutorio fidei, scilicet quod in felicitate illa attenditur ratione fruitionis.'

20 SH I, P1, Tr3, Q3, M4, C5 (n. 127), p. 198: 'Quia igitur philosophi nunquam pervenerunt ad cognitionem gratiae vel boni gratuiti (...).'

21 SH IV, P1 In1, Tr1, Q1, C1 (n. 1), p. 6: 'Secundum catholicam veritatem concedendum est humanam naturam esse lapsam, quod tamen philosophi ignoraverunt (...).'

22 SH II, In4, Tr1, S2, Q3, Ti3, M2, C3, Ar4 (n. 401), p. 478: '[L]iberum arbitrium dupliciter potest considerari: uno modo (...) ut 'arbitrium' dicatur ab arbitrando rationali consideratione vel discernendo 


\section{The Philosophers' Wisdom}

There is more material about the SH's attitude to the philosophers' wisdom. That the authors considered them wise is made clear by the repeated references to them, and especially to the Philosophus himself, Aristotle, as authorities. Sometimes their views are rejected, but on many occasions they are followed. This significant, explicit presence of the pagan philosophers contrasts with their absence from the mid $12^{\text {th }}$-century Sentences of Peter the Lombard, although it is given far less emphasis than Abelard gives to the ancient philosophers in the various versions of his Theologia; and it is very limited compared to later $13^{\text {th }}$-century theological writing. Augustine indeed, is cited ten times as often as Aristotle. The importance for the authors of Anselm and Richard of St Victor is striking: their positions and arguments often fill the place that, a few decades later, would be taken by Aristotle.

How far did the SH consider the philosophers' wisdom extended? Usually, medieval thinkers considered most of the ancient philosophers to have argued for and held to the existence of a wholly good, eternal, immutable, omnipotent, omniscient God. The $S H$ is no exception, stating, for example, as an obvious point that does not need to be argued that

( ... ) the philosophers knew the highest true thing according to himself, that he is the first truth, and they knew that he was good and best and that he was most powerful, and that all things needed him. ${ }^{23}$

But the authors quickly explain that this knowledge, which is, as it must be for the philosophers, without grace, is merely knowledge of God through his effects. ${ }^{24}$

In the $12^{\text {th }}$ century, various thinkers had gone beyond attributing to the philosophers knowledge of a God with the attributes of perfect being theology. They claimed, citing Augustine, that the philosophers knew of the Trinity. Indeed, for Abelard they were equally good witnesses to divine triunity as the Old Testament prophets, if not better. Abelard's assertions rested on his refusing to draw a clear line between know-

quid eligat quidve recuset, 'liberum' autem eo quod in sua sit positum potestate, habens agendi quod velit possibilitatem; et secundum hoc poterant philosophi pervenire ad intentionem liberi arbitrii: hoc enim nihil aliud est quam potestas rationalis ad opposita. Alio vero modo dicitur liberum arbitrium quod habet iudicium rationis, non per quod sit idoneum pervenire ad ea quae ad Deum pertinent, sine Deo aut inchoare aut peragere: et hoc modo est unum principium meriti. Sicut ergo non pervenerunt philosophi ad intentionem meriti, quod est ex gratia et libero arbitrio, ita nec pervenerunt ad rationem liberi arbitrii in quantum sine ipso non est meritum (...).'

23 SH IV, P3, In1, Tr1, Q1, C1 (n. 606), p. 946: 'philosophi cognoverunt summum Verum secundum se, quia esset prima Veritas; item, cognoverunt quod ipsum erat bonum et optimum et quod erat omnipotentissimum et quod ipso omnia indigebant (...).'

24 SH IV, P3, In1, Tr1, Q1, C1 (n. 606), p. 948: 'duplex est cognitio de Deo: una est per effectus suos, et haec est sine gratia; alia est per praesentiam sui apud animam, haec autem non potest esse sine gratia. Primo modo cognoverunt philosophi Deum.' 
ing the special attributes of the Persons-power, wisdom and benignity-and their proper identities as Father, Son and Holy Spirit. ${ }^{25}$ But in his commentary on Romans, Peter the Lombard had insisted on this distinction, allowing that the philosophers knew the special attributes, but not the Persons themselves in their proper identities. ${ }^{26}$ The $S H$ insists that, in principle, the Trinity is knowable, but due to its corruption after the Fall, our intellect cannot reach this knowledge without the help of grace-and the authors are even able to quote Aristotle to back up this point. ${ }^{27}$ Moreover, picking up on a doubt expressed by Augustine and often repeated, the authors consider that the philosophers knew the special properties of only the Father and Son, because of their deficient knowledge of goodness, due among other things to their ignorance of its supreme manifestation in the Redemption:

( ... ) They are said to have failed in knowing the third person, because they failed in knowing goodness. They did so in many ways: first, because they did not know the most powerful effect of goodness, that is the Incarnation and the Redemption; secondly, because although they knew goodness, they did not worship it as highest, because they attributed their goods to themselves; thirdly because although they knew the special attributes of two of the Persons-power and wisdom-they did not have knowledge of the special attribute of the third person-goodness. ${ }^{28}$

Although their denial of the philosophers' knowledge of the Trinity can, then, be traced to the authors' emphasis on grace, their position would be the general one among $13^{\text {th }}$-century theologians. Moreover, unlike their great Franciscan successor, Duns Scotus, the authors accept that the philosopher's cognition of God, although limited and not as triune, is not in itself erroneous.

The middle, somewhat undecided position of the $\mathrm{SH}$ with regard to the philosophers' knowledge is also found on an issue that, just a few decades later, would sharply distinguish different attitudes to the reliability of pagan philosophy: the eter-

25 See Marenbon, Pagans and Philosophers, 77-80.

26 Peter Lombard, Collectanea in Epistolas D. Pauli (PL 191:1329 A): 'Non ergo illas tres personas ideo dicuntur intellexisse, quod eas distincte veraciter et proprie intellexerint: sed quia illa esse cognoverunt in Deo, quae illis tribus personis in sacra Scriptura frequenter solent distinctim ac specialiter attribui, scilicet potentia, sapientia, bonitas.' Cf. Peter Lombard, Sententiae I, d. 3, c.1, 9, 1:71.

27 SH I, TrInt, Q2, M1, C3 (n. 10), p. 19: ‘(..) per naturalem rationem de se non potest haberi cognitio Trinitatis secundum propria; tamen per naturalem rationem, adiutam per aliquam gratiam aut gratis datam aut gratum facientem, potest. Et ratio huius est: quia intellectus noster, obtenebratus per originalem corruptionem, deficit in iis quae verissime sunt; et ideo circa maxime intelligibilia deficit (...) Nec hoc est mirum, quia, sicut dicit Aristoteles, in Prima Philosophia: "Intellectus noster se habet ad manifestissima naturae sicut oculus noctuae ad solem”.' See also SH I, TrInt, Q2, M1, C3 (n. 10), Ad obiecta 3, p. 19.

28 SH I, TrInt, Q2, M1, C3 (n. 10), p. 19: ‘(...) dicuntur defecisse in cognitione tertiae personae, quia defecerunt in cognitione bonitatis. Et hoc multipliciter: primo, quia non cognoverunt potissimum effectum bonitatis, scilicet incarnationem et redemptionem; secundo, quia etsi bonitatem cognoverunt, non tamen ut summam et primam venerati sunt, quia sua bona sibi attribuerunt; tertio, quia etsi habuerunt appropriata duabus personis, scilicet potentiam et sapientiam, non tamen habuerunt appropriatum tertiae personae, scilicet bonitatem.' 
nity of the world. In the 1260s and 1270s, the Franciscans William of Baglione and, less straightforwardly, Bonaventure would hold that the non-eternity of the world can be demonstrated, and that the philosophers had erred in their reasoning when they argued that it is eternal. Aquinas, by contrast, along with some of the Arts Masters, held that there is no demonstration that the world had a beginning; it is purely a matter of faith. ${ }^{29}$ The $S H$ argues that an eternal world-that is, a world which lacks a beginning of its duration-is an impossibility, because nothing can be created and lack a beginning (an idea Aquinas would reject), and the createdness of the world is evident to reason. ${ }^{30}$ But the authors also touch on the idea that there is really no dispute here with the philosophers, because they were merely concerned with lower causes. ${ }^{31}$ This line of thought, however, is taken from Philip the Chancellor's Summa de bono, and from Alexander of Hales himself, and the authors of the $S H$ make it much less clear and emphatic. ${ }^{32}$

\section{The Salvation of the Philosophers}

The third strand of the Problem of Paganism concerns salvation-in the $S H$, the salvation of the philosophers. Christian doctrine makes faith in the Redeemer a requirement for salvation. It was, indeed, widely held in the Middle Ages that the Gospel had been preached throughout the world, so that, arguably, most of those who did not believe in Christ were guilty of rejecting this belief. But this accusation could not be raised about those who lived before Christ. It was accepted that there were good Jews among those in the Old Testament, who would have been savednot just the prophets and leaders, who were thought to have had the future coming of the Messiah revealed to them, but ordinary Jewish people of those times. Theologians had at least to explain how their salvation, without faith in Christ, was possible. And they might also want to consider the case of an ancient, non-idolatrous pagan, who has led a virtuous life, such as one of the philosophers.

In his epistle to the Hebrews (6:6) St Paul says that 'without faith it is impossible to please God. For he that cometh to God, must believe that he is, and is a rewarder to them that seek him' (Douai Translation). The authors believed that it was within

29 On the controversy, see Richard Dales, Medieval Discussions of the Eternity of the World, Brill's Studies in Intellectual History, 18 (Leiden: Brill, 1990), 39-177 and Cyrille Michon, Thomas d'Aquin et la controverse sur L'Éternité de monde (Paris: Flammarion, 2004). For the reasons why, pace Michon, Thomas d'Aquin et la controverse, 47-55, Bonaventure did hold that it could be demonstrated that the world is not eternal, see Marenbon, Pagans and Philosophers, 141-2.

30 SH I, P1, In1, Tr2, Q4, M2, C4 (n. 64), p. 95.

31 SH I, P1, In1, Tr2, Q4, M2, C4 (n. 64), p. 98.

32 Philip the Chancellor, Summa de bono, De bono naturae, q. 3, 2 vols, ed. Nikolaus Wicki, Corpus Philosophorum Medii Aevi: Opera Philosophica Mediae Aetatis Selecta, 2 (Berne: Franke, 1985), 1:49; Dales, Medieval Discussions of the Eternity of the World, 68-9 (for editions of texts by Alexander of Hales). 
the power of human reason, without the aid of revelation, to discover this Pauline Minimum:

In natural law, following the dictate of reason, there was written a command about faith in the Mediator, in so far as in a certain way faith in the redemption was innate in human reason, because it could be certain to human reason that the nature of man had fallen in general. Now, it was innate to reason that always what is better and more worthy should be attributed to the highest goodness, and from this they did not have to go far to gather that the highest goodness would not permit that the rational human creature, which had perished in general, would perish entirely ( ... ) And so reason dictated that it should believe in the future restitution of humankind. In this way therefore it is shown that the command with regard to faith in the redemption is in a certain way written in natural law..$^{33}$

But, from the time of Hugh of St Victor, it had been generally accepted that belief in the Pauline Minimum was not sufficient for salvation. ${ }^{34}$ The $S H$, following Hugh's De sacramentis closely, but in using perhaps for the first time about faith the terms implicite and explicite, explains how, none the less, the simple Jews of the Old Testament were saved:

One can believe explicitly or implicitly, distinctly or indistinctly. The simple people are said to believe all the articles implicitly or indistinctly, and this in two ways. In one way with regard to what they believe; in the other way with regard to those with whom they believe. ${ }^{35}$

The authors explain implicitness with regard to faith in what in terms of generality: $\mathrm{X}$ cognizes $a$ (for instance, the Redemption) only in general, as in the Pauline Minimum, but X can be said to have implicit faith in all its details. They explain the implicitness with regard to those 'with whom they believe' in terms of vicarious faith: $\mathrm{X}$ does not personally cognize $a$ or at least not in detail, but $\mathrm{X}$ is willing to accept whatever Y believes, and Y has the relevant beliefs about $a$ and its details. The authors do not restrict this theory of implicit faith to the simple Jews of the Old Testament. A deaf person who has been baptized will through the grace of baptism come to under-

33 SH IV, P3, In2, Tr2, Q1, C3, Ar1 (n. 700), p. 1118: 'In lege naturali secundum dictamen rationis scriptum erat praeceptum de fide Mediatoris, in quantum indita erat quodam modo rationi humanae fides redemptionis, quia certum poterat esse rationi humanae naturam hominis esse lapsam generaliter. Inditum autem erat rationi quod semper melius et dignius est attribuendum summae Bonitati, et ideo satis ex propinquo colligere poterat quod summa Bonitas non permitteret rationalem creaturam humanam, quae generaliter perdita erat, ex toto perire (...) Et ideo dictabat ratio quod credere deberet futuram hominis reparationem. Per hanc ergo viam ostenditur in lege naturali quodam modo scriptum praeceptum de fide redemptionis.'

34 Cf. Marenbon, Pagans and Philosophers, 168-9.

35 SH IV, P3, In2, Tr2, Q1, C4, Ar1 (n. 702), p. 1120: 'Ad hoc breviter est dicendum quod est credere explicite vel implicite, distincte vel indistincte. Simplices autem implicite dicuntur credere omnes articulos sive indistincte, et hoc duobus modis: uno modo quantum ad illud quod credunt; alio modo quantum ad illos cum quibus credunt.' Cf. Hugh of St Victor, De sacramentis I, p. x, c. 7 (PL 176:339D340C). 
stand, when he or she reaches the age of reason, that he should believe what the Church believes. ${ }^{36}$ It is not, then, that the deaf person comes to understand explicitly the articles of faith, but merely to know in what-the Church-to put trust.

The theory of implicit faith will not help in the case of the philosophers. First, according to the authors, they did not recognize that humans are fallen and so, arguably, they did not even reach the Pauline Minimum, since they did not see the need for a redeemer. Second, there is no group which has explicit faith in Christ (such as the Old Testament prophets) to which they can plausibly be said to have given their faith. The authors have to turn to a different theory when, in a single short passage, they deal directly with the question of the salvation of the philosophers:

It is asked about the philosophers whether they have all been damned, for the sacrament of the incarnation was not revealed to them ( ... )

St Paul responds to this question about the philosophers (Rom. 1:21-22): "Because that, when they knew God, they have not glorified him as God ( ... ) and their foolish heart was darkened. For professing themselves to be wise, they became fools.” The evil philosophers, then, who took for themselves the glory which is God's, were blinded, and no revelation of the incarnation was made to them ( ... ) With regard to the good philosophers, however, I believe thus-that a revelation was made to them, either through Scripture, which the Jews had, or through prophecy or through internal inspiration, as was the case with regard to Job and his friends: "God resisteth the proud, and giveth grace to the humble" (James 4:6). And the same should be understood about the other simple pagans (gentiles). ${ }^{37}$

The suggestion, then, is that in one way or another, the good philosophers were able to be in the same position as the Jewish leaders (rather than the simple Jewish people). Rather than believe vicariously, they were in a position to believe directly, by having the Incarnation revealed to them in advance, through the Old Testament, prophecy or internal inspiration.

This idea of internal inspiration is one that seems to have originated with Abelard and to have been used by a number of later thinkers, including Aquinas, although the channels of transmission are not clear. Appeal to internal inspiration was usually, however, restricted to what were thought to be the rare cases of people

36 SH IV, P3, In2, Tr2, Q2, Ti3 (n. 707), pp. 1141-2. Note here, and also with the answer in the same place about the simple Jews (p. 1141), that the vicarious faith element alone is retained.

37 SH IV, P3, In2, Tr2, Q2, Ti3 (n. 707), p. 1141: 'Quaeritur ergo de philosophis utrum omnes sint damnati universaliter. Eis enim sacramentum incarnationis non fuit revelatum (...) [R]espondet Apostolus de philosophis, Rom. 1, 21: "Cum cognovissent Deum, non sicut Deum glorificaverunt”; et sequitur: "Obscuratum est insipiens cor eorum; dicentes enim se esse sapientes stulti facti sunt." Mali ergo philosophi, qui sibi usurpant gloriam quae Dei est, excaecati sunt; nec est eis facta revelatio incarnationis (...) De bonis vero sic credo quod eis facta fuerit revelatio, vel per Scripturam, quae apud Iudaeos erat, vel per prophetiam vel per internam inspirationem, sicut fuit de Iob et amicis eius; "Dominus enim superbis resistit, humilibus autem dat gratiam”, Iac. 4, 6. Similiter et de aliis simplicibus gentilibus intelligendum est.' 
who, after the preaching of the Gospel, had no chance to hear it. ${ }^{38}$ If the authors really want to suggest that a wide range of ancient pagans, both philosophers and simple people, were inwardly inspired with the knowledge they needed for salvation, then they are putting forward an unusual and daring, though highly implausible, theory. But this is just a passing remark, not repeated by the authors elsewhere, and only one possibility out of three-a sign less of radical thinking than the authors' lack of serious interest in the Problem of Paganism.

\section{Maimonides and the Anthropological Approach to Paganism}

This, then, is a good moment to turn away from the Problem of Paganism, to investigate the other, anthropological strand of the SH's treatment of pagans. What do the authors have to say about the religious phenomena of paganism? The most important passage in the $\mathrm{SH}$ for answering this question is a long and interesting discussion about pagan ceremonies in Book 3, in order to provide a rationale for the ceremonial precepts of the Old Law. ${ }^{39}$ But the material here, and the way of using it to explain the Bible, goes back to Moses Maimonides. It is worth pausing to consider the authors' exact relationship to Maimonides and his writings, both because it adds to the picture of how the $\mathrm{SH}$ uses Arabic sources and it throws light on the extent of the authors' interest in an anthropological approach to paganism.

In his Guide of the Perplexed, written in Arabic and finished by about 1190, Moses Maimonides explains how the various ceremonial precepts of the Old Law, many of which seem to be unnecessary or even absurd, were decreed by God in order to wean the Jews away from the idolatry of the Egyptians, and so cannot be understood except by reference to the particular customs of the Egyptians and other pagans. ${ }^{40}$ This approach is known as the theory of 'accommodation'. Although the line of thought can be traced back to early Jewish and Christian sources, Maimonides brings to it an exceptional knowledge of pagan customs, which he had searched out in all the Arabic sources he could find. ${ }^{41}$ The Guide was translated into Hebrew very soon after its composition by Samuel ibn Tibbon and again, after 1204, less accurately by Yehuda al-Harisi. Sometime before the mid $13^{\text {th }}$ century, a complete Latin translation

38 See Marenbon, Pagans and Philosophers, 92-3, 172-6.

39 SH IV, P2, In3, Tr2, S3, Q2 (n. 518), pp. 763-83; and cf. SH IV, P2, In3, Tr2, S3, Q3, C2 (n. 520), p. 786. 40 Moses Maimonides, Rabi Mossei Aegypti Dux seu Director dubitantium aut perplexorum (hereafter, Guide) III, cc. 30 - 33 [in modern editions: III, cc. 29-32], ed. Augustinus Iustinianus (Paris: ab Iodoco Badio Ascensio, 1520), fols 90r-93v.

41 For an excellent introduction to Maimonides' theory, see Sarah Stroumsa, Maimonides in his World: Portrait of a Mediterranean Thinker (Princeton: Princeton University Press, 2009), 84-105. 
was made of al-Harisi's version, and it was used by Albert the Great, Thomas Aquinas and later theologians. ${ }^{42}$

According to the received picture, the $S H$ is at the forefront of the reception of the Guide, and John of La Rochelle, who was responsible for Book 3, showed a serious interest in Maimonides' anthropological approach to paganism. Although the editors of the critical edition of the $\mathrm{SH}$ consider that the material on paganism for the discussion of the ceremonial precepts was taken indirectly from William of Auvergne's De legibus, they suggest that the authors knew the Guide and used various parts of it at a number of points. In a classic study of Old Testament commentary in the $13^{\text {th }}$ century, Beryl Smalley not only accepted that the authors made use of the Guide elsewhere in the $\mathrm{SH}$, but also claimed that, in the passage on the ceremonial precepts, $\mathrm{De}$ legibus was 'supplemented ( ... ) by a direct study of the Guide'. ${ }^{43}$

The most recent writer to examine the early Latin influence of the Guide, Görge Hasselhoff, taking account of the fact that there were other translations of the Guide besides the complete one, has qualified this view of the relationship between the $S H$ and Maimonides, without entirely rejecting it. ${ }^{44}$ The earliest of the partial versions is the Liber de parabola, not a straightforward translation, but rather a compilation mainly occupied by a version of the Guide III, Chapters 29 to 30 and 32 to 49 (including, therefore, Maimonides' discussion of the ceremonial precepts and pagan practices), ${ }^{45}$ with some additional matter added by its writer-apparently a learned Jew, writing for the work's dedicatee, Cardinal Romanus, in 1223 to $1224 .{ }^{46}$ It was this text, it seems, and not the complete translation of the Guide, which may well not even have been made at the time, that William of Auxerre used in De legibus. ${ }^{47}$ The Liber de uno Deo benedicto, from the early 1240s or before, is a translation of the Guide II, Introduction and Chapter 1 (Maimonides' argument for the existence of God), probably based on ibn Tibbon's Hebrew version. ${ }^{48}$ Hasselhoff argues that neither of the two explicit references to Maimonides in the $S H$ shows that the authors were using the complete translation. One, to 'Rabbi Moyses et alii philosophi', about

42 See Wolfgang Kluxen, 'Literargeschichtliches zum lateinischen Moses Maimonides,' Recherches de théologie ancienne et médiévale 21 (1954): 23-50; Görge K. Hasselhoff, Dicit Rabbi Moyses: Studien zum Bild von Moses Maimonides im lateinischen Westen vom 13. bis zum 15. Jahrhundert, 2nd ed. (Würzburg: Königshausen and Neumann, 2004).

43 Beryl Smalley, 'William of Auvergne, John of La Rochelle and Thomas Aquinas on the Old Law,' in St. Thomas Aquinas, 1274-1974: Commemorative studies, 2 vols, ed. Armand Maurer (Toronto: Pontifical Institute for Mediaeval Studies, 1974), 1:11-71, reprinted in Beryl Smalley, Studies in Medieval Thought and Learning: From Abelard to Wyclif, History Series, 6 (London: Hambledon, 1981), 160. 44 Görge K. Hasselhoff, 'The Reception of Maimonides in the Latin West: an introductory survey,' Jewish Studies Quarterly 9 (2002): 1-20.

45 The omitted Chapter 31 is little more than an aside by Maimonides.

46 Kluxen, 'Literargeschichtliches zum lateinischen Moses Maimonides,' 41-6.

47 Kluxen, 'Literargeschichtliches zum lateinischen Moses Maimonides,' 44-5.

48 See Kluxen, 'Literargeschichtliches zum lateinischen Moses Maimonides,' 36-41 and Hasselhoff, Dicit Rabbi Moyses, 88-93; for the use of ibn Tibbon, see Hasselhoff, Dicit Rabbi Moyses, 90, n. 4. 
animals made from putrefaction, is hard to track down to any given passage by Maimonides. ${ }^{49}$ The other, by contrast, correctly attributes to 'Rabbi Moyses Iudaeus' a distinction between ceremonial and judicial precepts. But this remark, Hasselhoff says, could have been taken either from Roland of Cremona, or from an oral source. ${ }^{50}$ Neither of these brief citations requires that the authors had read the Guide. On several occasions throughout the $S H$, the editors mention the Guide, which they cite in its early modern Latin translation, as a source. Hasselhoff thinks that some of these parallels may point to the use of the Liber de uno Deo, ${ }^{51}$ and he also suggests the possibility that the long passage on paganism and the ceremonial precepts is not taken from William of Auvergne but from the Liber de parabola. ${ }^{52}$

An even more radical view might be taken, however: perhaps the authors did not even know either of the two partial translations. The unmentioned parallels the editors have found with the Guide, except for the passage on the ceremonial laws, are unconvincing. For instance, the authors are said to have drawn the arguments they attribute to the philosophers for the eternity of the world from the Guide. But, in fact, the resemblance between their list and Maimonides' discussion is partial and superficial..$^{53}$ Furthermore, Hasselhof's suggestion that the Liber de parabola, rather than William of Auvergne, might have been used for the passage on the ceremonial laws, is unconvincing, given that other materials from De legibus are used extensively in this part of the $S H$.

The attitudes of John of La Rochelle, author of Book 3, are brought out by a passage earlier in this book, which is also concerned with the ceremonial precepts. The distinction between ceremonial and judicial laws made in Book 2 is repeated, but John chooses to drop the explicit reference to Maimonides as its originator: it is now attributed to 'a certain Jewish expositor of the law' (quidam Expositor Legis Hebraeus). ${ }^{54} \mathrm{~A}$ little before this reference, there is a discussion of how the ceremonial laws for which there is no other explanation were given to the Jews to win them over from idolatry-a crude but not inaccurate summary of Maimonides' position. This view is attributed to 'the Jewish literal expositors of the Law' (Iudaei expositores Legis ad litteram). ${ }^{55}$ The phrasing suggests that it may have been gathered from con-

\footnotetext{
49 SH I, P1, In1, Tr4, Q4, C6 (n.162), p. 242; Hasselhoff, 'The Reception of Maimonides in the Latin West,' $15-6$.

50 SH IV, P2, In3, Tr1, Q1, C5, Ar1 (n.263), p. 377. See Hasselhoff, 'The Reception of Maimonides in the Latin West,' 17-8. As Dag Hasse notes, however, Roland's Summa exists only in a couple of MSS written in Italy and did not circulate widely in Paris. See Dag Nikolaus Hasse, Avicenna's De anima in the Latin West: The Formation of a Peripatetic Philosophy of the Soul, 1160-1300 (London: The Warburg Institute, 2000), 63.

51 Hasselhoff, 'The Reception of Maimonides in the Latin West,' 16-7.

52 Hasselhoff, “The Reception of Maimonides in the Latin West,' 17.

53 Compare SH I, P1, In1, Tr2, Q4, M2, C4 (n. 64), Contra 12-16, pp. 94-5 with Moses Maimonides, Guide II, c. 14 , fols $46 \mathrm{r}-47 \mathrm{v}$.

54 SH IV, P2, In3, Tr1, Q2, C1 (n. 265), p. 384.

55 SH IV, P2, In3, Tr1, Q2, C1 (n. 265), p. 384.
} 
versations with Jews, rather than from a written text. John does not seem to see the link between this comment and the long passage taken from De legibus later in Book 3, where, like William of Auvergne there, he gives no hint of its Jewish origin.

John's attitude is thrown into relief by the fact the Liber de parabola was indeed most probably known in the world of the Paris University Franciscans, since it had been used by none other than Alexander of Hales himself, as Smalley noticed. ${ }^{56}$ What she claimed to be the first Latin use of the Guide, in the earliest version of Alexander's Sentences Commentary from the mid-1120s, is not, as the editor points out, from the standard complete translation. ${ }^{57}$ Alexander is summarizing rather than quoting, so it is difficult to be certain about the source. But the evidence points to the Liber: the quotation is from part of the Guide III, Chapter 35, included there; the biblical references are, like those in the Liber, close to the Vulgate; ${ }^{58}$ and Alexander does not know the name of the expositor, but says he is not a Christian -exactly what could be inferred from the Liber. ${ }^{59}$

John of La Rochelle is only, then, very incidentally and indirectly an early reader and user of Maimonides' anthropological approach to paganism. But his colleagues who wrote Book 2 do some independent thinking of their own in this area in their discussion of idolatry. They believe that, in principle, people of all times could discover that there is one supreme God, who is to be worshipped, and not idols. Although they comment that idolatry takes place because people follow the 'inclination of corrupted nature', they accept that it can be avoided, even by ungraced fallen humans, since the pagan philosophers were not idolaters. Idolatry comes about, rather, through a failure of reasoning:

Although humans consider God to be most good, most powerful and most wise-and these <descriptions > do not fit an idol or the spirit in charge of an idol, none the less, human reason, look-

56 Smalley, 'William of Auvergne, John of La Rochelle and Thomas Aquinas on the Old Law,' 135. Hasselhoff, 'The Reception of Maimonides in the Latin West: an introductory survey,' 18, who insists on treating the $\mathrm{SH}$ as a work by Alexander, seems not to have noticed Smalley's discovery and says that there are no references to Maimonides in any of Alexander's 'other edited works.'

57 The passage is at Alexander of Hales, Magistri Alexandri de Hales Glossa in quatuor libros Sententiarum Petri Lombardi (hereafter, Glossa) III, d. 37, n. 3, vol. 3, Bibliotheca Franciscana Scholastica Medii Aevi, 14 (Quaracchi: Collegium S. Bonaventurae, 1954), 3:471.12-472.7.

58 There are two biblical citations. The first (Alexander of Hales, Glossa, 3:471.15) is of Lev. 19:32. It is not found in the full text translation of the Guide and the wording, coram cano capite, is that of the Vulgate. The second (Alexander of Hales, Glossa, 3:471.22) is of Deut. 16:18. Here the comparison is: Alexander Constituantur iudices in portis; Vulgate iudices et magistros constitues in omnibus portis; Moses Maimonides, Guide III, c. 36 [in modern editions: III, c. 35], fol. 94v, Iudices et praepositos habebis in singulis ciuitatibus tuis. For the use of the Vulgate in De parabola, see Kluxen, 'Literargeschichtliches zum lateinischen Moses Maimonides,' 42.

59 He begins the extract by saying: 'Quidam expositor, licet non sanctus, dicit quod sunt summae praeceptorum quatuordecim in faciendo vel non faciendo.' (Alexander of Hales, Glossa, 3:471.12-14). 
ing at the effect and not universally but particularly, and deceived through this, fell into idolatry. ${ }^{60}$

The authors raise as a possible explanation for the rise of idolatry the intellectually undeveloped state of the earliest humans after the Fall: people 'greatly adhered to things of the senses'. Their intellects did not ascend to God but remained rooted to sensible things and believed that they should pray to them for aid. ${ }^{61}$ But this explanation is rejected, because it does not take account of the closeness of the earliest people to the creation, which they learned about through their ancestors, and which stopped them from worshipping creatures rather than the creator. Indeed,

Although they were simple because of the fact that not so much had been left for them in scriptures, from which they could become learned, as happened later on, their natural capabilities were better than those of the people who came afterwards, and with their better natural understanding (ingenium), along with grace, which was not lacking then, they were better able to resist the devil's machinations than in later times, so far as the goodness of natural things was concerned. ${ }^{62}$

Sin, according to the author, was something that gradually took hold of people, through example, beginning with the attractions of the body, and leading through power and pride to the greatest sin of all, idolatry. Here the authors seem to be influenced by a current of thinking that was Pelagian in origin, but was diffused under orthodox guise in Pelagius' Letter to Demetriades, misattributed to Jerome. ${ }^{63}$ The Jews, the authors go on to explain, remained free from idolatry for longer than other peoples because they were instructed by Abraham and the patriarchs, who themselves were taught by God. They fell into idolatry when their leader, Moses, left them to be given the Law on Mount Sinai and the idol they chose to worship was a calf because-and here John apparently engaged in his own anthropological research, they were influenced by their period in Egypt, where a cow or bull, dedicated to Serapis, was worshipped.

It is a sign, perhaps, of what little attention John of La Rochelle was paying to the Maimonidean material he copied from William of Auvergne in Book 3 that he does

60 SH III, In3, Tr8, S1, Q1, Ti1, C2 (n. 733), p. 719: 'Licet homo ponat Deum esse summe bonum, summe potentem, summe sapientem - haec autem non conveniunt idolo vel spiritui in idolo praesidenti - nihilominus tamen ratio humana respiciens ad effectum, et non universaliter, sed particulariter, et per hoc decepta, incidit in idololatriam.'

61 SH III, In3, Tr8, S1, Q1, Ti1, C6, Ar1 (n. 737), p. 725: 'Plurimum adhaerent homines rebus sensibilibus.'

62 SH III, In3, Tr8, S1, Q1, Ti1, C6, Ar1 (n. 737), p. 726: 'Licet simplices essent propter hoc quod tot non erant relicta in Scripturis, ex quibus erudirentur, sicut in posterioribus temporibus factum fuit, meliora tamen naturalia habebant quam homines qui postea fuerunt, et ex meliori ingenio naturali cum gratia, quae tunc non defuit, poterant melius resistere machinationibus diaboli quam in posteriori tempore, quantum est de bonitate naturalium.'

63 Epistola I: Pelagii ad Demetriadem (PL 30:15-45); see esp. PL30:19D-20C. 
not seem to notice that there is a complete contradiction between the theory his colleagues had developed in Book 2 about the origins of idolatry among the Jews and that on which the account adopted from William supposes. Maimonides' explanation of the ceremonial laws is based on the idea that, when they received the Old Law, the Jews had long become accustomed to idolatry and needed careful direction to be weaned from it. According to $S H$, however, the first incident of Jewish idolatry was the worship of the golden calf.

\section{Conclusion}

The Problem of Paganism is the result of an essential tension in Latin Christian culture in the long Middle Ages, but it comes to the foreground only for a select group of thinkers; for most, it manifests itself only occasionally, here and there. The $S H$ clearly belongs in this larger group. The authors lack the devotion to classical antiquity that made the Problem of Paganism so pressing for thinkers like Abelard or Dante, whilst real contemporary pagans, as opposed to Muslims, seem-in the period before the Mongol threat-to have been beyond their purview. The SH's treatment of paganism is most interesting in its anthropological treatment of pagan religious phenomena, such as idolatry. Although the use of Maimonides, the great pioneer in this field, is unengaged and indirect, the authors are not afraid to develop their own ideas on the subject. 